\title{
Caráter persuasivo e estrutura organizacional panóptica: as narrativas do Instituto Nacional do Livro e o Plano de Divulgação de Obras Bibliográficas no Brasil
}

\author{
Alessandra Nunes de Oliveira \\ Doutoranda; Universidade Estadual Paulista "Júlio de Mesquita Filho", Marília, SP, Brasil; \\ alesandra.nunes@unesp.br; https://orcid.org/0000-0002-7662-5686 \\ Jetur Lima de Castro \\ Doutorando; Universidade Estadual Paulista "Júlio de Mesquita Filho", Marília, SP, Brasil; \\ jetur.castro@unesp.br; http://orcid.org/0000-0002-6445-4576

\section{Luiz Eduardo Ferreira da Silva} \\ Doutor; Universidade Federal do Paraíba, João Pessoa, PB, Brasil; \\ luizeduardo.ufpb@gmail.com; https://orcid.org/0000-0001-6232-5319
}

\begin{abstract}
Resumo: Investiga as narrativas apresentadas no Plano Nacional de Divulgação de Obras Bibliográficas (PNDOB) sobre as medidas de implementação da difusão cultural dos livros e das bibliotecas no Estado Novo no Brasil. Por meio da apropriação documental do Arquivo de Gustavo Capanema e de jornais da época, a pesquisa percorreu o caminho da Análise Crítica do Discurso (ACD), com base na análise do conteúdo e de imagens sobre os caminhos e as ações adotadas pelo Instituto Nacional do Livro (INL), com o objetivo de analisar como ocorreu e se estruturou o PNDOB. A utilização das fontes documentais foi necessária para discutir sobre como as ações do INL foram largamente difundidas em uma estrutura de caráter persuasivo e panóptico, por meio da qual o PNDOB foi instituído com o objetivo de monitorar e de controlar os livros, aplicados à instituição disciplinar, visando à correção e à ordem em nome da moral e dos bons costumes. Por essa razão, questionou-se até que ponto é possível considerar que as publicações e as iniciativas criadas pelo INL eram benéficas para a sociedade do período do Estado Novo, pois, mesmo existindo toda a aparente disseminação dos livros e das bibliotecas, outros tipos de livros foram considerados nocivos para a sociedade e procurados em todos os cantos do Brasil para saírem de circulação. Os resultados indicaram o PNDOB do INL com uma estrutura persuasiva e panóptica e um volume próximo de 88 folhas, entre inúmeros gráficos, organogramas e planejamentos. Conclui-se que é possível pensar sobre se as ações do INL encontraram uma atitude benéfica, uma vez que foi detalhadamente organizada em favor da educação e da cultura varguista da constante expansão da informação sob a ordem de controle bibliográfico, e como aconteceu o acesso ao conhecimento e às políticas de informação por meio dos livros no Brasil.
\end{abstract}

Palavras-chave: Estado Novo - Brasil. Instituto Nacional do Livro. Censura. Controle de obras bibliográficas. 


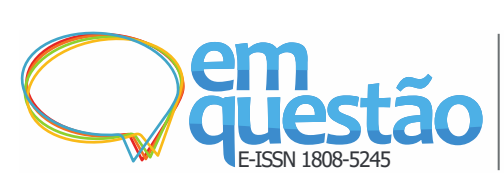

Caráter persuasivo e estrutura organizacional panóptica: as narrativas do Instituto Nacional do Livro e o Plano de Divulgação de Obras Bibliográficas no

Brasil

Alessandra Nunes de Oliveira, Jetur Lima de Castro, Luiz Eduardo Ferreira da Silva

\section{Introdução}

A difusão cultural dos livros e das bibliotecas no Estado Novo, no Brasil, é o ponto central que deu início à criação do Plano de Divulgação de Obras Bibliográficas (PNDOB) instituída pelo Ministério da Educação e Saúde em 1938. Antes, porém, precisamos saber de onde veio a inciativa de fazer o PNDOB. Em outras palavras, como se constituiu a informação registrada e institucionalizada do Instituto Nacional do Livro (INL), encontrada no arquivo de Gustavo Capanema. Para nós, com a apropriação documental, é possível fazer essa investigação a partir de um olhar discursivo e crítico para analisar as narrativas que constam no referente plano sobre as medidas de implementação da difusão cultural dos livros e bibliotecas no Estado Novo no Brasil.

Nesse sentido, a pesquisa tem uma abordagem qualitativa, construtiva e contributiva, que busca remodelar e arranjar a maneira de se pensar sobre o INL e sobre a difusão da cultura dos livros por meio da narrativa documental. Nossa ideia é "[...] tornar pública a produção de conhecimentos gerados ou organizados por uma instituição. A noção de acesso à informação é comumente interpretada como equivalente à difusão ou mesmo de divulgação." (LARA; CONTIN, 2003, p. 26).

Além disso, o estudo traz uma contribuição que, conforme Darnton (2016), refere-se à história dos livros assistidos pelo controle do Estado e a atuação de seus bastidores. Neste caso, trata-se, especificamente, do controle dos livros pelo Estado Novo, com articulações planejadas do INL, com o intuito de vigiar a escrita, o conteúdo e o discurso presentes nos livros, a fim de permitir ou proibir os fluxos do conhecimento de acordo com seus interesses e as forças políticas e ideológicas.

Essa contribuição se refere à história dos livros, a qual, sob o olhar interdisciplinar da Ciência da Informação (CI), “[...] investiga as propriedades e o comportamento informacional, as forças que governam os fluxos de informação e os significados do processamento da informação, visando à acessibilidade e a uma usabilidade ótima." (BORKO, 1968, p. 3), e da Biblioteconomia, que aplica aspectos instrumentais da CI, tendo como aspecto 
Alessandra Nunes de Oliveira, Jetur Lima de Castro, Luiz Eduardo Ferreira da Silva

central o tratamento e o provimento da recuperação e do acesso aos registros bibliográficos. Nesse âmbito, sustenta-se ao apresentar a revitalização do discurso das ações e das políticas culturais do livro implantadas pelo INL, no período do Estado Novo no Brasil, por intermédio da narrativa documental e do PNDOB. Pautada na visão de Darnton (2016), a documentação sobre o PNDOB é um fio condutor que traz pressupostos sobre como o Estado Novo instituiu os bastidores do controle e da censura.

Para nós, isso é fundamental, uma vez que podemos analisar, de forma crítica, algumas concepções a partir da apropriação da história, de registros documentais, narrativos e imagéticos, numa perspectiva alinhada com a CI, a história do livro e a bibliografia. Nesse sentido, o corte discursivo trata da forma como o pesquisador trabalha com as ideias construídas das representações, com os símbolos e as ações do tempo histórico em que está inserido. Assim, tomamos o pensamento de Ricoeur de que, “[...] na memória, há uma significação do passado, o qual é retratado através da narrativa do tempo histórico vivido.” (RICOEUR, 2007, p. 174).

Nesse aporte, considera-se a compreensão qualitativa da informação institucionalizada encontrada no PNDOB, no arquivo de Gustavo Capanema e em jornais impressos digitalizados. Os documentos pesquisados caracterizam-se como procedimentos da análise documental, que

[...] consiste em fazer um intenso e amplo exame de diversos materiais que ainda não sofreram nenhum trabalho de análise, ou que podem ser reexaminados, buscando-se outras interpretações ou informações complementares, chamados de documentos. (KRIPKA; SCHELLER; BONOTTO, 2015, p. 244).

Assim, a pesquisa documental é uma fonte primária, riquíssima e estável em dados históricos, que visa representar o conteúdo de um documento em uma forma diferente do original, a fim de facilitar a informação de forma condensada e interpretativa (MARCONI; LAKATOS, 2010; BARDIN, 2009).

As informações coletadas tiveram como base, a priori, o acervo digital do Centro de Pesquisa e Documentação de História Contemporânea do Brasil (CPDOC) da Fundação Getúlio Vargas (FGV), o arquivo de Gustavo Capanema (2021) e jornais da época que foram consultados na Hemeroteca Digital da 
Biblioteca Nacional (HDBN). Somando as fontes coletadas, nossa observação percorreu o caminho da Análise Crítica do Discurso (ACD), com o auxílio da análise do conteúdo e de imagens sobre os caminhos e as ações adotadas pelo INL, com o objetivo de analisar como ocorreu e se estruturou o PNDOB.

A ACD, de acordo com Van Dijk (2018), estuda o modo como as características do contexto, tais como as propriedades dos usuários da língua de grupos poderosos, influenciam as formas dos membros dos grupos dos dominados. É uma análise do discurso de vertente inglesa, porque nosso objetivo se estrutura no exame do PNDOB, na imagem do livro produzido pelo Estado Novo e em alguns jornais que embasam a pesquisa rigorosamente para analisar como o INL influenciava o público com o discurso com a manipulação de imagem.

Sob o ponto de vista de Van Dijk (2018, p. 251), a manipulação de imagens é feita "[...] por meio do discurso em um sentido mais amplo, isto é, incluindo características não verbais, como gestos, expressões faciais, layout de texto, imagens, e assim por diante.". Estudar a forma como foi estruturado o PNDOB tipifica os discursos dos primeiros pontos centrais desta pesquisa, desvelando as intencionalidades em relação à imagem sobre a difusão da cultura do livro objetivada pelo Estado Novo. As representações visuais, que se encontram no material documental, são o que chamamos de análise de imagens, na qual visamos a refletir, compreender, descrever e contextualizar diferentes perspectivas e teorias dessa abordagem, com o objetivo de decifrar as significações que a "naturalidade" aparente das mensagens visuais implica. A "naturalidade" é alvo suspeito para os que buscam investigar o que está por trás da imagem "espontânea” (JOLY, 1996, p. 43).

Por outro lado, a análise de conteúdo nos possibilita fazer inferências que se relacionam ao motivo da criação de determinado enunciado e às enunciações, isto é, o que diz respeito às causas e às consequências das mensagens e seus efeitos, à produção dos sentidos que podem ser encontrados nos enunciados do PNDOB e dos jornais, a partir das estruturas semânticas, linguísticas e das 


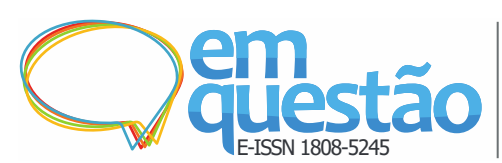

Caráter persuasivo e estrutura organizacional panóptica: as narrativas do Instituto Nacional do Livro e o Plano de Divulgação de Obras Bibliográficas no

Brasil

Alessandra Nunes de Oliveira, Jetur Lima de Castro, Luiz Eduardo Ferreira da Silva

estruturas sociais e psicológicas. Tais concepções são abordadas por Bardin (2009, p. 43), que esclarece:

A leitura efetuada pelo analista, do conteúdo das comunicações, não é, ou não é unicamente, uma leitura à letra, mas antes o realçar de um sentido que se encontra em segundo plano. Não se trata de atravessar significantes, para atingir significados, à semelhança da decifração normal, mas atingir através de significantes ou de significados (manipulados), outros significados de natureza psicológica, sociológica, política, histórica etc.

Nesse contexto, a análise de conteúdo se torna profícua, uma vez que trabalha com a fala e com a prática da língua realizada por emissores identificáveis (BARDIN, 2009). Sob o ponto de vista de Bardin (2009), através da análise de conteúdo e por meio de um mecanismo de dedução com base em indicadores construídos, a pesquisa visa a conhecer o que está implícito nas palavras e as significações dos enunciados que mais aparecem nos documentos primários. Dessa forma, percorre os caminhos e as ações adotadas pelo INL e sua política institucional de informação. Nossa intenção foi de examinar essa narrativa descrita no PNDOB tratando-a com a dinâmica enunciativa e imagética que se difundiu no governo Vargas sob a ação do INL.

Assim, os resultados identificados indicam que o PNDOB do INL se apoia numa estrutura persuasiva e se embasa na aproximação conceitual sobre controle e vigilância a partir do pensamento panóptico implicado no PNDOB que o INL instituiu. Assim, diretamente, "[...] precisa ser compreendida articuladamente com outras mediações históricas e comunicativas que se completam com a pluralidade de ressignificações e apropriações." (MORIGI; SEHN; MASSONI, 2014, p. 312).

Portanto, é possível pensar se as ações do INL encontraram uma atitude benéfica, uma vez que foi detalhadamente organizada em favor da educação e da cultura varguista em relação à constante expansão da informação sob a ordem de controle bibliográfico, de como aconteceu o acesso ao conhecimento e às políticas de informação por meio dos livros no Brasil. O PNDOB do INL elenca uma estrutura persuasiva e panóptica com um volume próximo de 88 folhas, entre inúmeros gráficos, organogramas e planejamentos, que induziram à propagação dos livros e das bibliotecas no Brasil. 
Alessandra Nunes de Oliveira, Jetur Lima de Castro, Luiz Eduardo Ferreira da Silva

\section{Aproximações sobre controle e vigilância a partir do pensamento panóptico}

Sob o ponto de vista de Santos e Portugal (2019), o termo panóptico surgiu com a figura arquitetural criada pelo filósofo inglês, Jeremy Bentham, que, etimologicamente, significa visão de tudo (pan = tudo) óptico (visão). O filósofo escreveu uma sequência de 21 cartas, em pós-escritos, sobre o plano panóptico na Rússia, as quais foram enviadas à Inglaterra em 1787. Em nome da moral reformada, Bentham retratou nas cartas um plano que tinha como escopo o controle e a disciplina e poderia ser executado em qualquer instituição com o propósito de manter sob vigilância determinados números de pessoas.

$\mathrm{Na}$ primeira carta, Bentham esclarece o princípio da inspeção, explicando como se sucede o regime em que "ele é aplicável [...] a todos e quaisquer estabelecimentos, nos quais, num espaço não demasiadamente grande para que possa ser controlado ou dirigido a partir de edifícios, queira-se manter sob inspeção certo número de pessoas.” (BENTHAM, 2000, p. 17). Assim, entende-se o panóptico como a estrutura que garante um plano de monitoramento e controle, que pode ser aplicado em diferentes instituições disciplinares ou fiscalizadoras, com o propósito de corrigir e disciplinar através da inspeção. Essa aplicação faz com que a pessoa realmente tenha a sensação de estar sendo vigiada para não cometer atos de indisciplina. Interessante salientar: Bentham pronuncia que a pessoa deve pensar que está sendo inspecionada.

Em sua segunda carta, Bentham esclarece as características do plano e os princípios de construção para a casa de inspeção. Os estabelecimentos que o referido autor retrata podem ser executados em uma casa de inspeção penitenciária. Ele estabelece, de modo "arquitetal", a ideia geral do plano com edifícios de modo circular e contendo os apartamentos dos prisioneiros, que ele chama de celas. É o que Foucault chama de "efeito mais importante do Panóptico", isto é, induzir, para aquele que está sendo observado, um estado consciente e permanente de visibilidade que assegura o funcionamento automático do poder (FOUCAULT, 1987, p. 166), atuando em vigilância, fazendo a extensão da contínua observação, que antes era do externo e, agora, 
passa a fazer parte do doutrinamento social, produzido pelo conhecimento, isto é, de como poder agir a partir de nichos especializados.

Uma das mais importantes preocupações de Michel Foucault referese às formas concretas de manifestações do poder. Precipuamente as limitações produzidas no regime de saber, nas verdades produzidas pelo conhecimento, as quais ligam diretamente as formas de controle e de doutrinamento de corpos, domesticados em prol de condutas desejáveis esperadas pelo corpo social. A partir de exemplos históricos perquire e esmiúça as engrenagens montadas e colocadas em funcionamento pelos detentores de determinadas posições de mando. Ainda que exista farto material de registro do pensamento desenvolvido por ele, suas obras efetivamente publicadas como livro trazem referências a nichos localizáveis de atuação do poder, sem tentar realizar generalizações e abstrações absolutizantes. (LOURENÇO, 2009, p. 17).

Podemos entender essa concepção a partir das normas, dos controles e das punições estabelecidas no regime do Estado Novo com o PNDOB autenticado pelo INL para as instituições que trabalham com informação e documentação, como as bibliotecas. Essa ação de autocontrole desencadeou ações de censura e repressão da livre expressão literária e informacional, que, por meio das ações do INL, convergiram para que o próprio "eu” dos indivíduos se regulamentasse sobre o conhecimento diante das condições estabelecidas pela instituição.

Leitão (2010, p. 102), em sua tese de Doutorado, exemplifica essa ação de controle e ressalta que o próprio INL foi como uma gênese da censura com as obras bibliográficas e sua produção livresca, uma vez que, como órgão público, durante o Estado Novo, ele estava ligado ao governo, e isso repercutiu na necessidade de impor controle às "novas ideias democráticas" e contribuiu para que a cultura da censura no país se fortalecesse. Através desse papel, interferiu diretamente na produção livresca e nas bibliotecas públicas no Brasil.

Essa é uma relação que foi endereçada às bibliotecas a partir do PNDOB, desde a manutenção de normas para usuários que ali frequentam, como nos procedimentos profissionais dos bibliotecários. Assim, podemos ver o controle como umas das principais seções do PNDOB do INL e que, devido ao seu objetivo de controlar, se impôs a censura dos livros de educação e de literatura, principalmente aqueles dedicados à mocidade escolar (BRASIL, 1938f). 


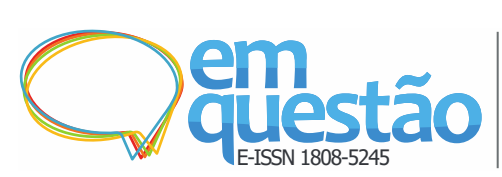

Caráter persuasivo e estrutura organizacional panóptica: as narrativas do Instituto Nacional do Livro e o Plano de Divulgação de Obras Bibliográficas no

Brasil

Alessandra Nunes de Oliveira, Jetur Lima de Castro, Luiz Eduardo Ferreira da Silva

Formas disciplinares de ação instituídas pelo INL, implicadas na censura punitiva, envolveram bibliotecas, autores, publicações e até leitores, cujo objetivo era instituir a ideologia do poder dominante. Por isso, foi construído o PNDOB, que, mais à frente, traria duras consequências pela via do controle e da punição (CASTRO; OLIVEIRA, 2017). Conforme os autores, a punição também ocorre de forma aparentemente "sutil" e "inofensiva", mas se manifesta em animosidade ou exclusão, algo que iremos ver mais adiante na narrativa.

Foucault (1987, p. 12) revela o "desaparecimento do suplício", dando margem à existência da punição de maneira indireta. Segundo ele,

\begin{abstract}
punições menos diretamente físicas, uma certa discrição na arte de fazer sofrer, um arranjo de sofrimentos mais sutis, mais velados e despojados de ostentação, merecerá tudo isso acaso um tratamento à parte, sendo apenas o efeito sem dúvida de novos arranjos com maior profundidade (FOUCAULT, 1987, p. 12).
\end{abstract}

No que se refere ao ato disciplinar, que foi o PNDOB, estabeleceram-se regras disciplinares sem ao menos buscar soluções para aplicá-las melhor, inclinando-se ao condicionamento do acesso à informação por meio da censura imposta pela ordem hegemônica, a qual foi instituída pelo INL com efeito de repressão, internalizada e seguida como uma forma de condição/troca para que se desejem utilizar os serviços de informação expandidos por todo o Brasil.

As instruções normativas impostas no PNDOB começaram a criar um controle normativo. Percebemos os comandos enunciativos do plano, tais como 'Objetivo educacional do livro', 'Inquéritos diversos', 'Colaboração alheia', 'Publicidade geral' e 'Controle', em que ações dominantes tomaram forma e se estenderam por meio dos planos que reportam descrições normativas que sugerem proibições e negações. Sobre essa situação, já não se estabelece a presença física (real presença), uma vez que o comando fiscalizador agora é um objeto que toma a forma de comando (dispositivo), como extensão do olhar panóptico. A onipresença da vigilância ocorre quando "[...] há uma diminuição do trabalho de inspeção sem que seu rigor seja diminuído." (BENTHAM, 2000, p. 26).

Nesse ponto, a sensação de vigilância contínua é desempenhada por um poder mental dominante sobre aqueles que o dizem. Logo, a dominação mental 
se constitui simbolicamente como uma forma de disciplina, a qual, como já explicitado, Foucault (1987, p. 166) chama de "o efeito mais importante do panóptico", assim como o que Bentham (2000, p. 24) diz "ser o ponto essencial do plano panóptico":

Você ficará satisfeito em observar que, embora o ponto mais importante seja, talvez, o de que as pessoas a serem inspecionadas devam sempre sentir-se como se estivessem sob inspeção ou, pelo menos, como tendo uma grande possibilidade de estarem sob inspeção. (BENTHAM, 2000, p. 25).

O INL estava disposto a dar especial atenção à educação que eles chamavam de "problema de educação moral" para remodelar a educação no Brasil, dar-lhe um novo sentido e orientá-la a partir da moral cívica de nação, na formação de caráter e de patriotismo, narrativa que veremos a seguir, a partir da criação do INL e do PNDOB, trazendo o conteúdo que trata sobre a supervisão, o controle e a censura de obras que não condiziam com o ideal moral político do Estado Novo. As obras bibliográficas que fossem contrárias à coesão espiritual e à unidade moral não convergiam com a nova política educacional, e a consequência era a suspensão da circulação dessas obras.

\section{Instituto Nacional do Livro (INL)}

O Ministério da Educação e Saúde tinha o objetivo de promover, em todo o país, os serviços destinados ao desenvolvimento integral da personalidade humana, visando a abranger as atividades concernentes à saúde. Por outro lado, tratar dos assuntos relativos ao preparo do espírito e ao seu contínuo aprimoramento (BRASIL, 1937, p. 1).

No que se refere aos assuntos da educação, o ensino físico e moral era defendido no centro do discurso educacional, "[...] para o fim de levar às massas, luzes novas, elevação de sentimento, estímulo, entusiasmo para o trabalho e devoção a pátria.” (BRASIL, 1937, p. 2). Porém, esses objetivos só poderiam ser disseminados através da difusão cultural das bibliotecas no Estado Novo, e isso foi o ponto central que deu início à propagação dos livros. Nesse contexto, o INL era responsável pela publicidade dos feitos do governo do 
Estado Novo por meio da propagação dos livros e da amplitude de bibliotecas em todo o território nacional.

O INL surgiu por iniciativa do Ministro da Educação e Saúde, Gustavo Capanema, e foi criado em 1937, depois de se emitir uma carta ao Presidente Getúlio Vargas, chamada de "Exposição de motivos", que explica a necessidade de criar um instituto por meio do qual o Estado pudesse facilitar sua produção e disseminação, mas também proteger para que os livros não fossem instrumentos do mal.

A seguir, um parágrafo da carta emitida:

O livro não é só o companheiro, amigo, que instrui que diverte, que consola. É ainda é, sobretudo, o grande semeador que, pelos séculos afora, vem transformando a face da Terra. É, portanto dever do Estado proteger o livro, não só promovendo e facilitando a sua produção e divulgação, mas ainda vigiando no sentido de que ele seja não o instrumento do mal, mas sempre inspirador dos grandes sentimentos e das nobres causas humanas. (CAPANEMA, 1937, p. 25586).

O espírito nacional, a grandeza da nação através da leitura e um homem novo para um Estado Novo são expressões constantemente encontradas nos documentos de Gustavo Capanema para justificar a criação do PNDOB do INL e os incentivos à educação.

Para explicar a criação do PNDOB, instituído por Gustavo Capanema, recorremos ao texto de Chartier (1998), segundo quem o livro sempre visou a instaurar uma ordem. Em suas múltiplas fisionomias, onde a escrita se instaura, o autor ressalta a ordem desejada pela autoridade que o encomendou ou permitiu sua publicação.

Podemos observar a explicação de Chartier considerando que Capanema, como autoridade, atribuiu uma grande importância aos livros, porém, de uma forma homogênea, já que seu interesse também era controlar e ordenar obras para que satisfizessem aos interesses do Estado, pois entendia que, a depender do livro, ele poderia ser utilizado para o "mal" de uma sociedade. "O INL deve observar a política da época como expressão da vontade popular para evitar que os escritores deem ao povo falsa concepção para a vida, falsa filosofia para o espírito e falsa educação para o caráter." 
(BRASIL, 1938d, p. 3). Essa orientação constitucional do plano explica que os livros devem ser direcionados para um ideal coletivo, para a perfeição do dinamismo nacional e para a glória do organismo político. As leituras devem propiciar suaves tendências espirituais e ideais mais nobres.

Dessa maneira, a orientação constitucional apresentada no PNDOB tratava de aspectos que limitavam a diversidade dos conteúdos dos livros. Pode ser apresentada, conforme Chartier (1998), como o processo ou ordem instaurada da materialidade da escrita em que, mesmo limitada, a liberdade de entendimento dos leitores pelas convenções e competências ainda soube como se desviar e reformular as significações que a reduziram.

Observamos essa ação quando Gustavo Capanema conferiu a justificativa para se criar o INL, a fim de ter uma instituição que promoveria livros como os de interesses mencionados na carta. Observamos, em seu discurso, a redução e a invisibilização das obras, quando ele diz que os livros eram considerados "maus" e recompõe o discurso afirmando que era legitimado com o ideal estado-novista para promoção e difusão. Assim, impulsionado pelo populismo da modernização, Getúlio Vargas atendeu ao pedido do Ministro Gustavo Capanema, por meio do Decreto-Lei nº 93, de 21 de dezembro de 1937, que transformava o Instituto Caiuru em Instituto Nacional do Livro, e entrou em vigor em 01 de janeiro de 1938, com a nomeação de Augusto Meyer para assumir sua direção (BRASIL, 1937, p. 1).

Capanema passou a se dedicar ao projeto do INL para além de cuidar dos interesses mais amplos do livro do Brasil e conquistar a simpatia do povo para que o referente instituto conseguisse concretizar os efeitos traçados (LEITÃO, 2010).

A sede do INL era localizada no quarto andar da Biblioteca Nacional Brasileira e se responsabilizou pelas publicações, pela circulação de livros, pela criação e pela manutenção de bibliotecas no território brasileiro e em baratear o custo de livros para que fossem usufruídos pela nação brasileira.

O Art. $2^{\circ}$. do decreto determinava que competiria ao INL:

a. Organizar e publicar a Enciclopédia Brasileira e o dicionário da Língua Nacional, revendo-lhes as sucessivas edições; 
Alessandra Nunes de Oliveira, Jetur Lima de Castro, Luiz Eduardo Ferreira da Silva

b. Editar toda sorte de obras raras ou preciosas, que sejam de grande interesse para a cultura nacional;

c. Promover as medidas necessárias para aumentar, melhorar e baratear a edição de livros no país bem como para facilitar a importação de livros estrangeiros;

d. Incentivar a organização e auxiliar a manutenção de bibliotecas públicas em todo o território nacional. (BRASIL, 1937, p. 1).

Assim, o Instituto buscou traçar a sua finalidade em nome dos mais "nobres espíritos" e divulgar obras literárias, artísticas e científicas. Entre as obras publicadas, estavam as históricas e, principalmente, as de teor didático, algumas em forma de cartilhas infanto-juvenis, cujo conteúdo abordava, explicitamente, o despertar do nacionalismo ou a figura de Vargas. Para divulgar essas obras, o INL cercava-se de estratégias de publicidade que fizessem a sociedade sempre ter a recepção dos ideais cívicos nacionalistas do Estado Novo.

Como uma instituição atrelada ao governo do Estado Novo, o INL contribuiu, de forma especial e efetiva, com esse processo, ao produzir e disseminar informações oficiais que serviam aos propósitos de um Estado burocrático, como apoio às suas decisões (GUGLIOTTA; GONZÁLEZ DE GOMES; FONSECA, 2017).

Na próxima seção faremos uma breve análise dos planos de divulgação presentes em conteúdos de livros, propagandeados, jornais e discursos de livros.

\section{Plano de Divulgação de Obras Bibliográficas (PNDOB)}

O documento em que constava o PNDOB, de 25 de julho de 1938, foi dividido em duas partes. A primeira se referia às duas espécies de deveres estabilizadores do seu equilíbrio, a saber: 1) Orientação Constitucional Brasileira; 2) Orientação Nacional Brasileira. A orientação do plano era de que a educação, como um ideal humano individual, reflete o homem e o ideal humano coletivo organismo social que reflete o povo. Por isso se defendia que a pedagogia e a política não se separam.

Como justificativa desse contexto, o documento citava pensamentos de alguns autores do campo da Filosofia, como Rousseau, Kant, Schiller, 
Schoppenhauer, que concordavam com o pensamento de Natorp de que "Estado e cultura respondem a um mesmo problema humano, portanto, social." (BRASIL, 1938d, p. 1).

A justificativa da utilização dessa breve citação é encontrada logo em seguida, quando o plano defende que o estadista é o ser educador e que ele deve consagrar todos os seus esforços à educação, porquanto a política é obra da educação, a qual prepara para transformações sociais.

Para melhor explicar essa abordagem da educação com a política e a sua influência social, o plano citou Rousseau e suas obras: Heloise (a reforma dos costumes sociais), Contrato social (a reforma dos costumes políticos) e Emílio (a reforma da educação do homem) como influência na revolução francesa e na América moderna, cuja educação tenta se aproximar do ideal de Rousseau.

Depois de toda a explicação sobre a educação e sua influência na política, no último parágrafo, é defendido o que seria a ideia de orientação constitucional:

É notável a influência dos grandes escritores sobre o espírito das massas populares e da mocidade acadêmica, amplamente sentida pela História e pela organização política e social. E esta correlação da obra constitucional e educativa revela a necessidade de controle de todos os livros escritos para o Brasil. (BRASIL, 1938d, p. 2).

Sabendo do poder do pensamento contido nos livros, mas que, conforme o plano, a educação deveria atentar para a política da época então vivenciada, um dos objetivos traçados para o INL era evitar que os escritores dessem ao povo falsa concepção para a vida, falsa filosofia para o espírito e falsa educação para o caráter, que são sentimentos desconexos, falsos e fortes o suficiente para perturbar o desenrolar das "ideias sadias". Conforme Brasil (1938d, p. 3), “O Instituto dará aos brasileiros leituras de suaves tendências espirituais, para a serenidade psíquica, o controle dos êxitos individuais, das energias aproveitadas, dos ideais mais nobres.". Para isso, o INL estava disposto a construir um plano para que o povo consumisse essas "ideias sadias" através das obras bibliográficas. 
Alessandra Nunes de Oliveira, Jetur Lima de Castro, Luiz Eduardo Ferreira da Silva

No que diz respeito à orientação nacional brasileira, estavam em pauta o ideal de linguagem e a palavra. Conforme o plano, é o manejo da linguagem que forma a união indissolúvel para que haja o espírito da raça, a união dos filhos da pátria e a conservação das cousas tradicionais. Segundo Brasil (1938, p. 2), “[...] o cultivo da linguagem deve trazer singeleza na forma, doçura no falar, harmonia na ideia, suavidade no gesto, canção na prosa, encantamento conjunto.”. O amor à língua é colocado em pauta quando ela é obedecida conforme as diretrizes em conjunto com os ideais de nação. $\mathrm{Na}$ abordagem da orientação nacional, a língua brasileira não é amada quando não é integrada ao mesmo espírito.

Neste ponto da orientação nacional, percebe-se que o discurso é direcionado para o espírito; o ideal psíquico, tanto para os que escrevem, quanto para os que leem. Assim, “[...] temos de procurar a perfeição no pensar que é a essência, porque a responsabilidade do homem também cresce [...]" (BRASIL, 1938e, p.1), e agir no ideal da boa leitura e usar bem as palavras contribuem para um bem coletivo espiritual.

Foi elaborado um organograma que consta no Plano Geral de Divulgação de Obras. Nesse gráfico, são abordadas as diretrizes que deveriam estar submetidas ao PNDOB do INL.

Vimos como o plano era traçado com detalhes para englobar o assunto das obras livrescas, desde o estímulo de uma forma geral que o livro deveria propiciar para a sociedade, até mesmo as supervisões do "cuidado" com as palavras, a linguagem com que os conteúdos dos livros deveriam ser expressados, a fim de levar bons costumes de leveza e espiritualidade para a nação, com o intuito de evitar o escândalo. 


\subsection{Plano de Divulgação de Obras Bibliográficas (PNDOB): publicização e nacionalização do livro}

Em um breve resumo, esse plano visa a alcançar, de preferência, as necessidades práticas de educação, antes das vantagens sociais de cultura. O ponto central era que as obras atendessem aos anseios patrióticos e, consequentemente, as bibliografias fossem divulgadas em todo o país e cercassem os leitores de forma direita ou indireta, para que eles pudessem sempre estar em contato com as divulgações feitas.

As estratégias de divulgação do PNDOB consideravam a própria publicidade do plano. O interesse em torno dela emergia de forma natural, e, posteriormente, foi criando formas mais amplas de divulgação, como se pode constatar em Brasil (1938g), que assevera: “[...] publicidade será ativa em volta da nacionalização de livros, pelo aperfeiçoamento de nossa linguagem e em volta da sua constitucionalização, pelo sentido brasileiro dos livros." (BRASIL, 1938g, p. 1).

O plano era dividido em sete secções:
a) realizações preliminares;
b) objetivo educacional do livro;
c) matéria de divulgação;
d) inquéritos diversos;
e) colaboração alheia;
f) publicidade geral;
g) publicidade especial;
h) controle.

Realizações preliminares determinavam que era preciso fazer a publicidade do INL em torno do livro. Isso consistia em divulgá-lo no rádio, na imprensa, no cinema e nas associações de educação e cultura oficiais ou particulares, que "[...] orientam um plano de publicidade coletiva em torno do livro, com exposição futura de resultados estatístico e obras.” (BRASIL, 1938g, 


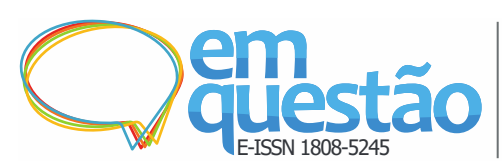

Caráter persuasivo e estrutura organizacional panóptica: as narrativas do Instituto Nacional do Livro e o Plano de Divulgação de Obras Bibliográficas no

Brasil

Alessandra Nunes de Oliveira, Jetur Lima de Castro, Luiz Eduardo Ferreira da Silva

p. 2). De fato, os jornais logo trataram de fazer a referida divulgação, não apenas do ideal do INL, mas também das bibliotecas que recebiam seu apoio.

Nesse contexto, ressalta-se o papel da imprensa no Brasil pós-1930 de assumir alguns momentos decisivos e de influência política, alcançando até mesmo o papel de protagonista, principalmente no que diz respeito aos grandes centros (Rio e São Paulo). Por isso, o movimento homogêneo e o novo papel dos jornais aderiram ao Estado, no período que passou a história como Estado Novo, quando os meios de comunicação ganharam relevo na difusão da ideologia estado-novista, fundamental para formatar o pensamento conservador brasileiro e para fazer uma revolução passiva (BARBOSA, 2006).

Assim, os jornais passaram a existir como palcos do movimento político do Estado Novo, pois, ao analisar os jornais dos anos de 1938 a 1945, vimos constantes notícias que abarcavam pequenos informes, editoriais e manchetes em primeira capa no cotidiano dos periódicos que circulavam no dia a dia trazendo à tona os feitos do INL para os seus leitores.

Figura 1 - Jornal Gazeta de Notícias, 14 de janeiro de 1938

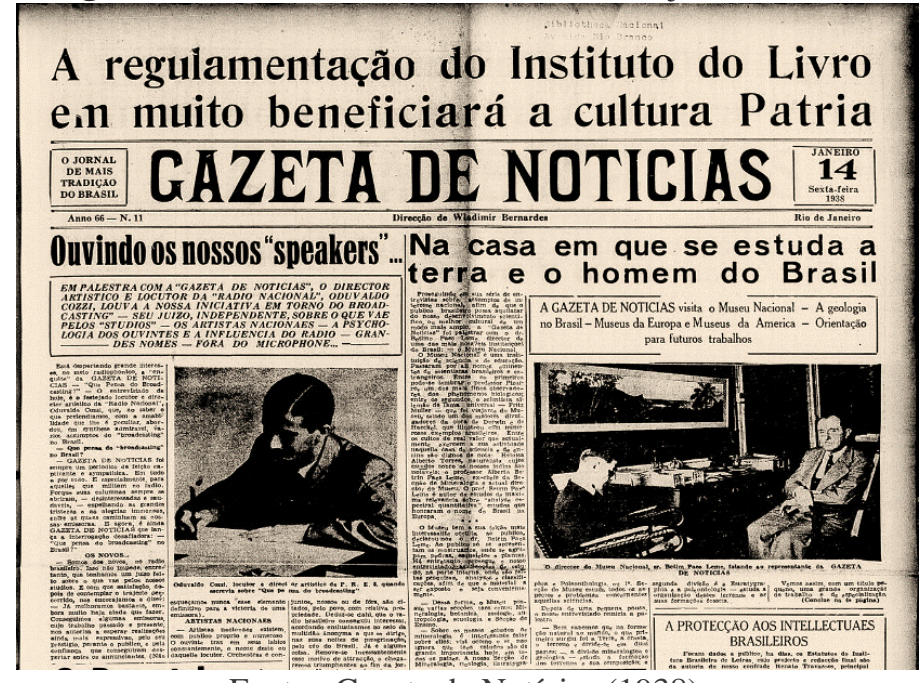

Fonte: Gazeta de Notícias (1938). 


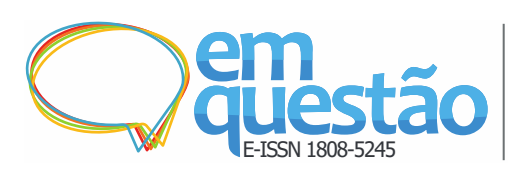

Caráter persuasivo e estrutura organizacional panóptica: as narrativas do Instituto Nacional do Livro e o Plano de Divulgação de Obras Bibliográficas no

Brasil

Alessandra Nunes de Oliveira, Jetur Lima de Castro, Luiz Eduardo Ferreira da Silva

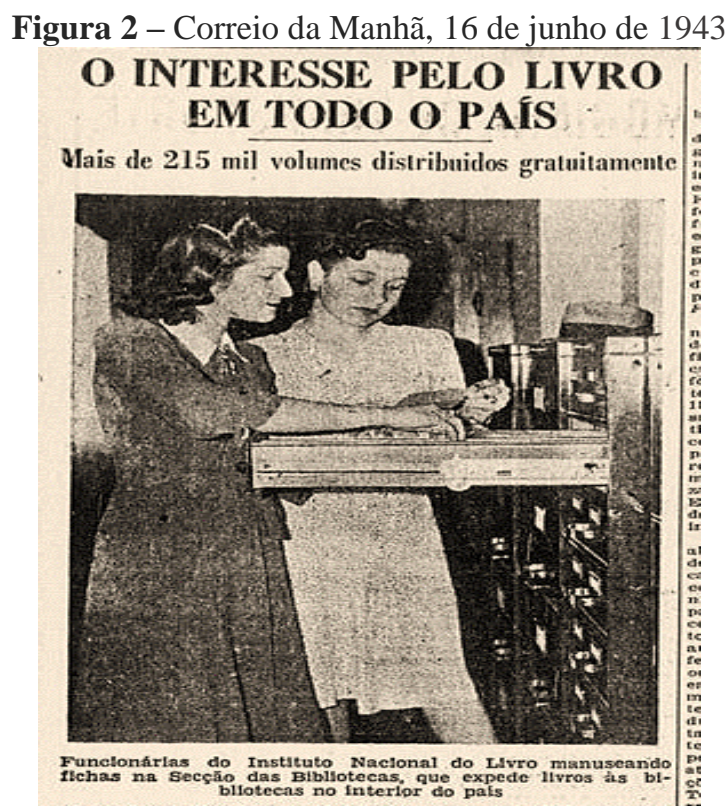

Fonte: Correio da Manhã (1943).

Na Figura 1, o jornal traz a referida manchete, mas não explica o que seria essa regulamentação e chama a atenção para o nome do INL, diferente da manchete da Figura 2, que aborda a quantidade de volumes distribuídos pelo órgão gratuitamente.

Na legenda da Figura 2, é possível observar a descrição que seria de duas funcionárias do INL manuseando fichas na secção das bibliotecas que expedem livros para as bibliotecas de todo o país.

Esses são apenas um dos exemplos das várias manchetes que os jornais começaram a divulgar sobre os ideais do INL e eram constantes as publicidades feitas nos jornais para o que seria o referente Instituto. Intelectuais, cultura e educação eram palavras frequentes nos discursos das colunas sociais e manchetes quando apresentavam a ideia cultural de Gustavo Capanema.

Barbosa (2006) explica que essa prática repercute nos discursos dos grandes acontecimentos do governo que reverberavam nos jornais, como forma de testemunhar para as massas a construção de um ideal de nação, no qual prevalecia a ideia de direcionamento político e intelectual. Uma vez divulgados, nos jornais, números e imagens sobre o alcance que o INL estava adquirindo, teatralizava-se todo o imaginário acerca de sua função nacional e não se deixava lacunas para questionamentos sobre o controle que ocorria. 


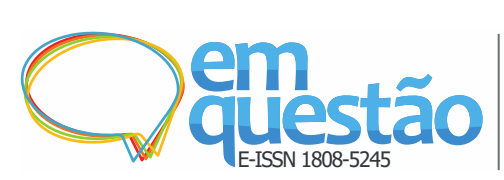

Caráter persuasivo e estrutura organizacional panóptica: as narrativas do Instituto Nacional do Livro e o Plano de Divulgação de Obras Bibliográficas no

Brasil

Alessandra Nunes de Oliveira, Jetur Lima de Castro, Luiz Eduardo Ferreira da Silva

Em nossa análise, nas secções do PNDOB, houve algumas inquietudes que, para nós, escondem-se nas entrelinhas. Recorremos a Darnton (2016) para compreender, e ele esclarece sobre os bastidores da censura, quando começam a surgir missões internas, que não podem ser analisadas pela superfície dos discursos. Assim, os bastidores sobre as diretrizes dos controles bibliográficos que o PNDOB propiciava revelam as intenções do governo estado-novista frente aos livros.

Observa-se a seção educacional do livro (b), que sugeriu adaptações de livros escolares à finalidade do ensino e da cultura nacionais, tendo como base a orientação nacional e pedagógica sobre o fato de a linguagem ser usada no espírito nacional.

Os livros deveriam ser adaptados para a nova linguagem nacional e "[...] visar o culto à linguagem brasileira, a formação do caráter individual, cultura geral, além do conhecimento perfeito do Brasil e do povo.”. (BRASIL, 1938g, p. 2), sendo que aqueles que não seguissem o direcionamento deveriam ser censurados "[...] a falta de livros evidentemente pedagógicos e de literatura escolar, estabelece a censura de livros para o Brasil.” (BRASIL, 1938g, p. 2).

Leitão (2010) certifica que a vigilância se configura de maneira intensa quando há essa forma de imposição sobre como deveriam ser arquitetadas as obras bibliográficas, para que fossem publicadas, o que levou a um modelo regimentar de publicação de obras, em que autores tivessem que se adequar às diretrizes enaltecedoras do governo; caso contrário, suas obras estariam proibidas de circular e censuradas.

Foram muitos os livros que seguiram a linha da nova adaptação da linguagem do espírito patriótico nacional. Foi a partir de um anteprojeto criado por Oswaldo Orico, onde estavam as bases da Constituição de 1937, que foram enviadas ao Ministro Gustavo Capanema, para que ele pudesse ler e converter em lei. Nesse anteprojeto, constavam os serviços bibliográficos em que as casas editoriais e as livrarias de todo o país " [...] ficam obrigadas sob pena de multa de cem mil reis, de cada vez, a enviar de 3 em 3 meses, a relação dos livros quaisquer que editarem - sejam originais, sejam traduções.” (BRASIL, 1939a, p. 6). Atentamos para os prejuízos comerciais causados pelas determinações 
Alessandra Nunes de Oliveira, Jetur Lima de Castro, Luiz Eduardo Ferreira da Silva

impostas pelo governo, em que as editoras logo forneceram as listas de livros editados que atendessem às diretrizes da nova política editorial de livros (LEITÃO, 2010).

Algumas das livrarias/editoras que mandaram suas listas foram: Livraria Editora Record, de São Paulo; Livraria Francisco Alves, do Rio de Janeiro; Livraria Pará e a Livraria Globo, de Belém do Pará; Chignone e Cia de, de Salvador - Bahia; Mercantil Souza e Belleza, de São Paulo; Empresa Editora Brasileira e Livraria Progresso.

Nas figuras abaixo, apresentamos alguns exemplos dessas listas.

Figura 3 - Livrarias paraenses com a lista de livros editadas

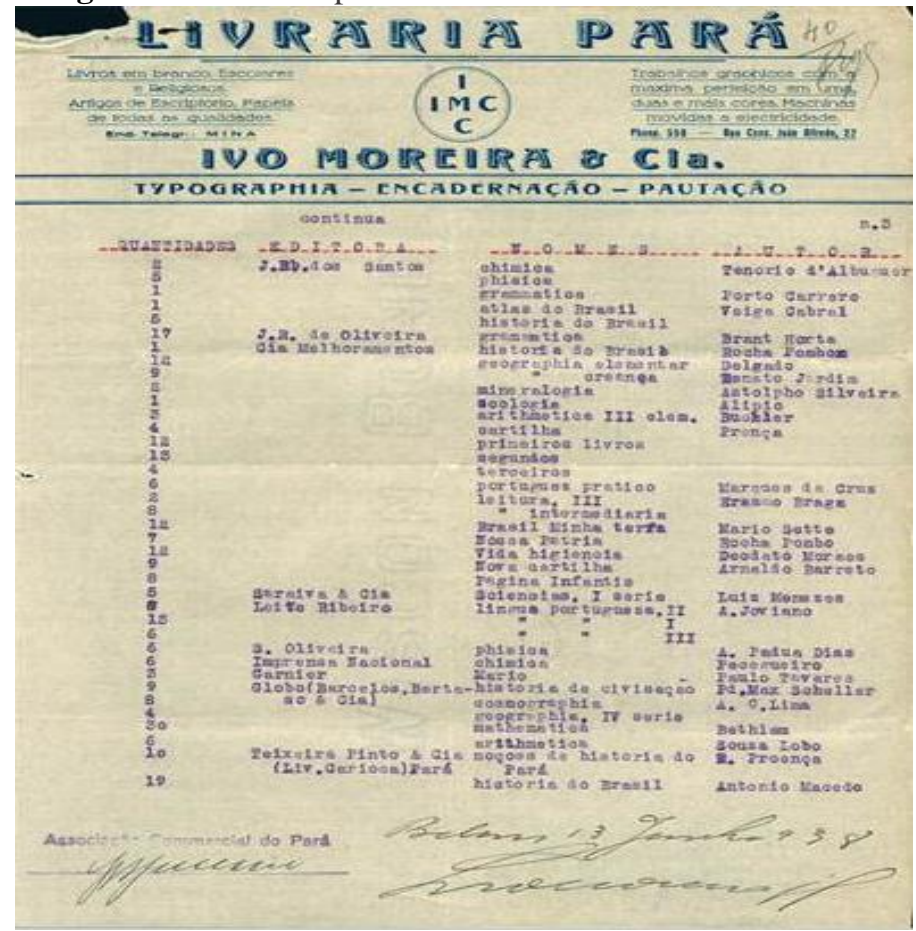

Fonte: Fundação Getúlio Vargas (1938a). 
Alessandra Nunes de Oliveira, Jetur Lima de Castro, Luiz Eduardo Ferreira da Silva

Figura 4 - Livrarias paraenses com a lista de livros editadas

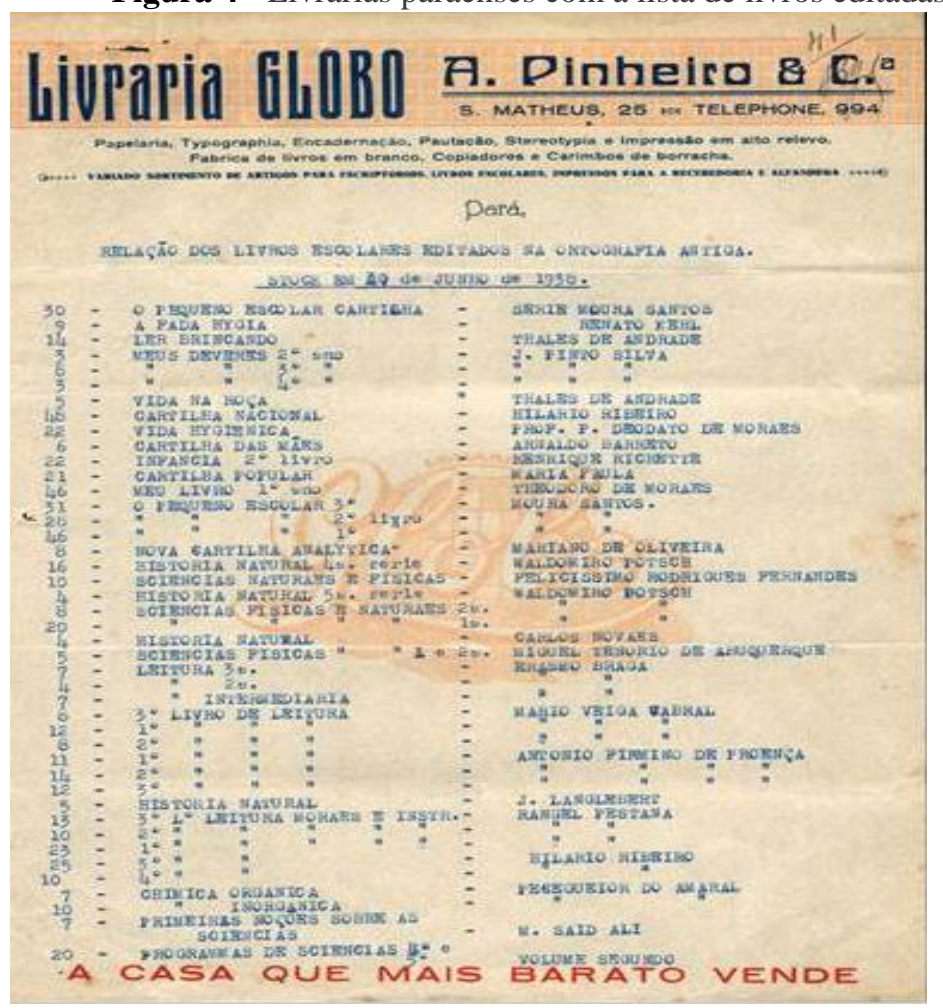

Fonte: Fundação Getúlio Vargas (1938a).

Figura 5 - Livraria Editora Chignone e Cia, Salvador - Bahia - Lista de livros editados

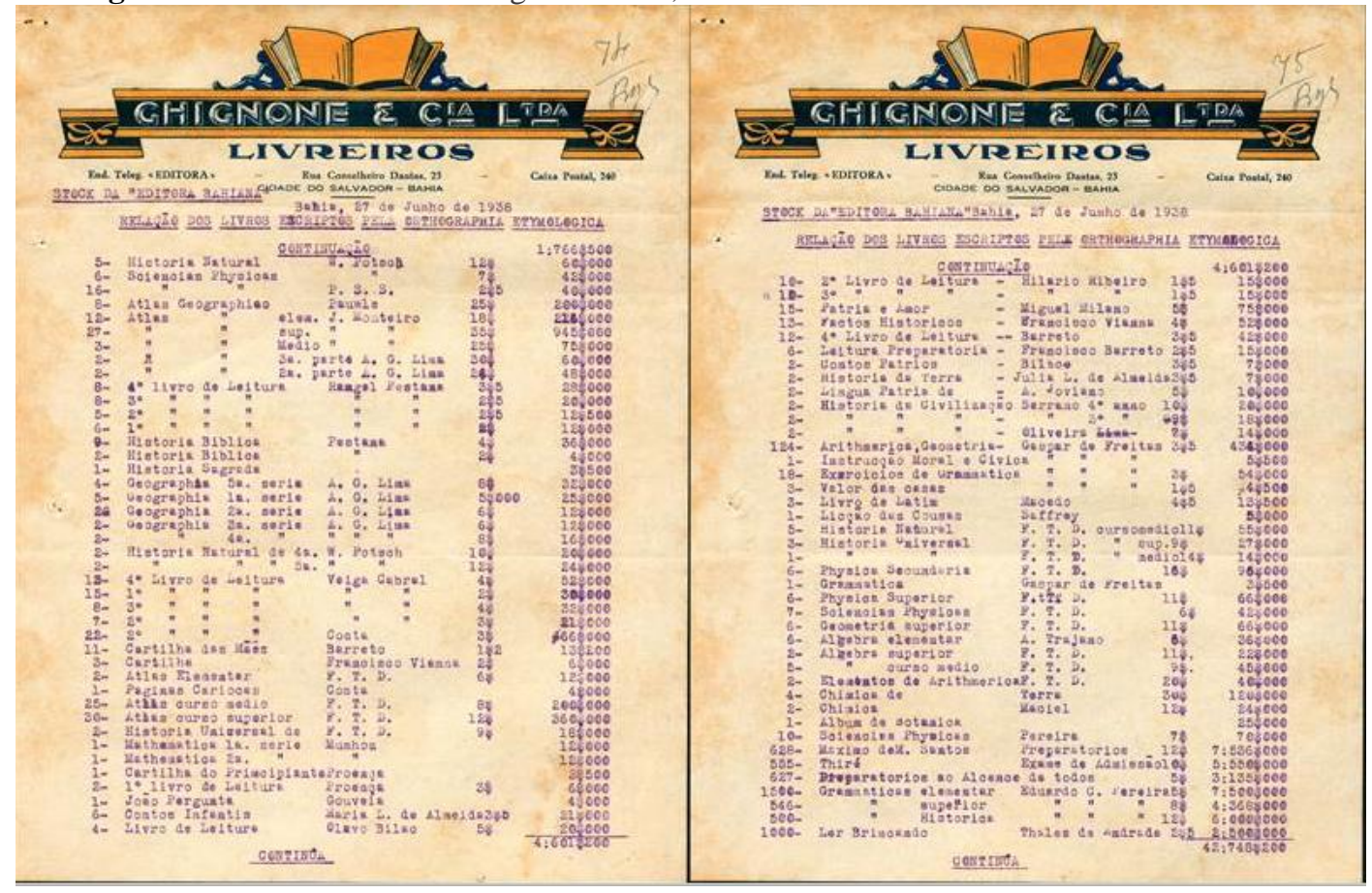

Fonte: Fundação Getúlio Vargas (1938b). 
Os livros de origem estrangeira também precisaram ser submetidos a uma relação de leis e atos oficiais para que o movimento intelectual das bibliografias se realizasse em espírito de unidade da nação brasileira, sem que houvesse coesão com os protocolos existentes no Brasil. O projeto chamado de 'Intercambio intelectual', em primeiro lugar, visava a reunir obras bibliográficas a um mesmo destino de pensamento (BRASIL, 1939b, p. 1).

Em se tratando da matéria de divulgação (c), o livro deveria ser disseminado conforme os assuntos de interesse direcionados ao público-alvo: operários, jovens, crianças e adultos. Projetando em seus conteúdos assuntos da educação e da cultura nacionais, as matérias eram estabelecidas de acordo com as classes sociais de estudantes, operários e profissionais: "Os assuntos de publicação são colhidos na literatura geral, infantil e juvenil, folclore brasileiro, história, geografia e língua brasileira, artes e ciências, educação em todos os seus aspectos, civismo e política nacional.” (BRASIL, 1938g, p. 2).

Inquéritos diversos (d) estabeleciam os lugares em que seriam disseminadas essas obras. Para isso, estavam inseridas as bibliotecas, que "[...] são indispensáveis para o conhecimento do valor das obras." (BRASIL, 1938g, p. 2). No documento chamado de demonstração dos trabalhos executados pela secção de literatura infantil de 1935 a 1938, foi atribuída a importância às bibliotecas e foi dito que a leitura que ela proporciona é como um bem do serviço público municipal, análogo ao dos hospitais e aos de luz, água e esgoto, portanto, devendo ser mantido pelo poder público.

A referida secção mencionada coincide com a colaboração alheia (e), cujo objetivo era de obter auxílio de todos os interessados nos objetivos sociais do INL, como os grandes meios de massa informacionais e comunicacionais - a imprensa, o rádio e o cinema - e os pequenos grupos de liderança. Assim, era defendido o fato de o plano ser traçado e orientado pelo INL,

[...] procurando atingir desde Academias de Letras, Secretarias de Estado, Prefeituras Municipais, até bibliotecas, colégios, universidades e associações. E deve procurar interessar os homens de valor, atrair departamentos, institutos, comissões do M.E.S, grêmios particulares etc. (BRASIL, 1938g, p. 2). 
Alessandra Nunes de Oliveira, Jetur Lima de Castro, Luiz Eduardo Ferreira da Silva

Aqui chegamos à publicidade geral (f), que diz respeito especificamente à publicidade das obras bibliográficas. Essa propaganda poderia ser feita individual e coletivamente. Nessa secção, defendia-se que a publicidade dos livros era importante para o Brasil tanto quanto sua publicação, e que, para isso, era necessário percorrer a divulgação em todas as esferas:

[...] pode a publicidade se valer de aulas em colégios ou universidades, de irradiações que acompanhem o movimento cultural do Brasil, de estatísticas intelectuais, filmes, revistas propagadoras de artes, de conferências ilustradas, de qualquer outro meio mais simples. (BRASIL, 1938g, p. 4).

Podemos ver, a seguir, a publicidade de livros na Revista Cultura Política, um periódico mensal de estudos brasileiros, no qual se observa a divulgação dos livros publicados no Brasil.

Figura 6 - Revista Cultura Política, 1941, p. 272

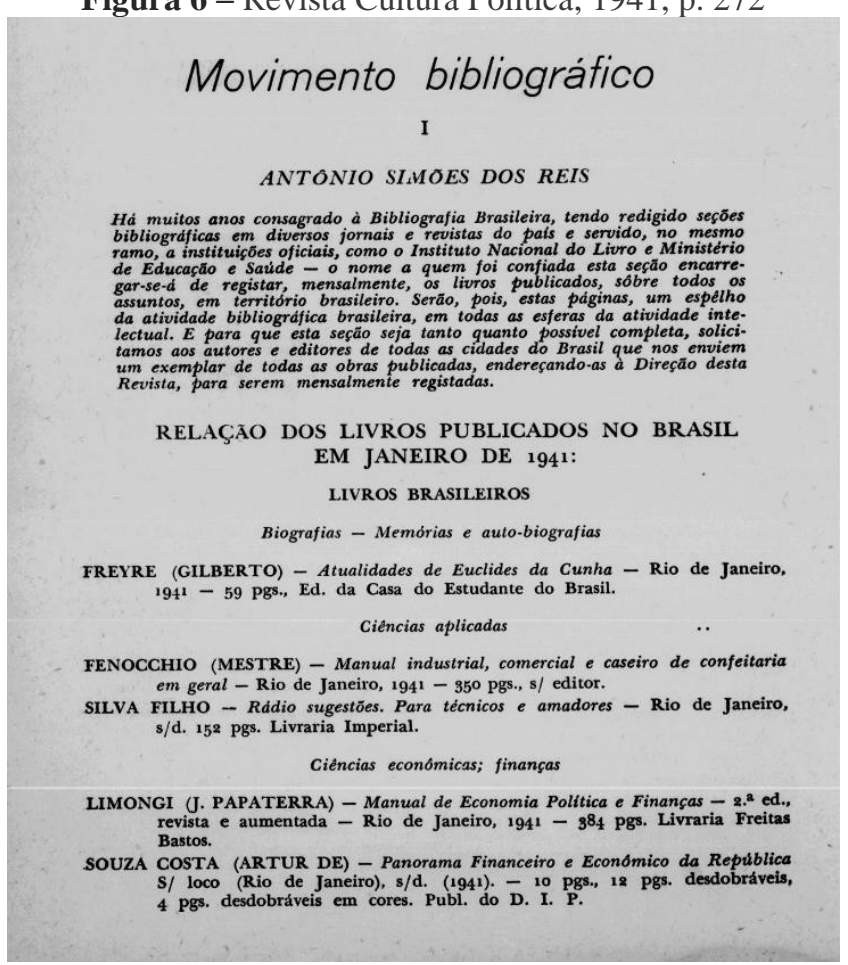

Fonte: Revista Cultura Política (1941). 


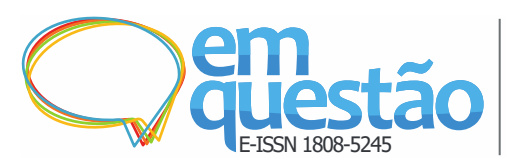

Caráter persuasivo e estrutura organizacional panóptica: as narrativas do Instituto Nacional do Livro e o Plano de Divulgação de Obras Bibliográficas no

Brasil

Alessandra Nunes de Oliveira, Jetur Lima de Castro, Luiz Eduardo Ferreira da Silva

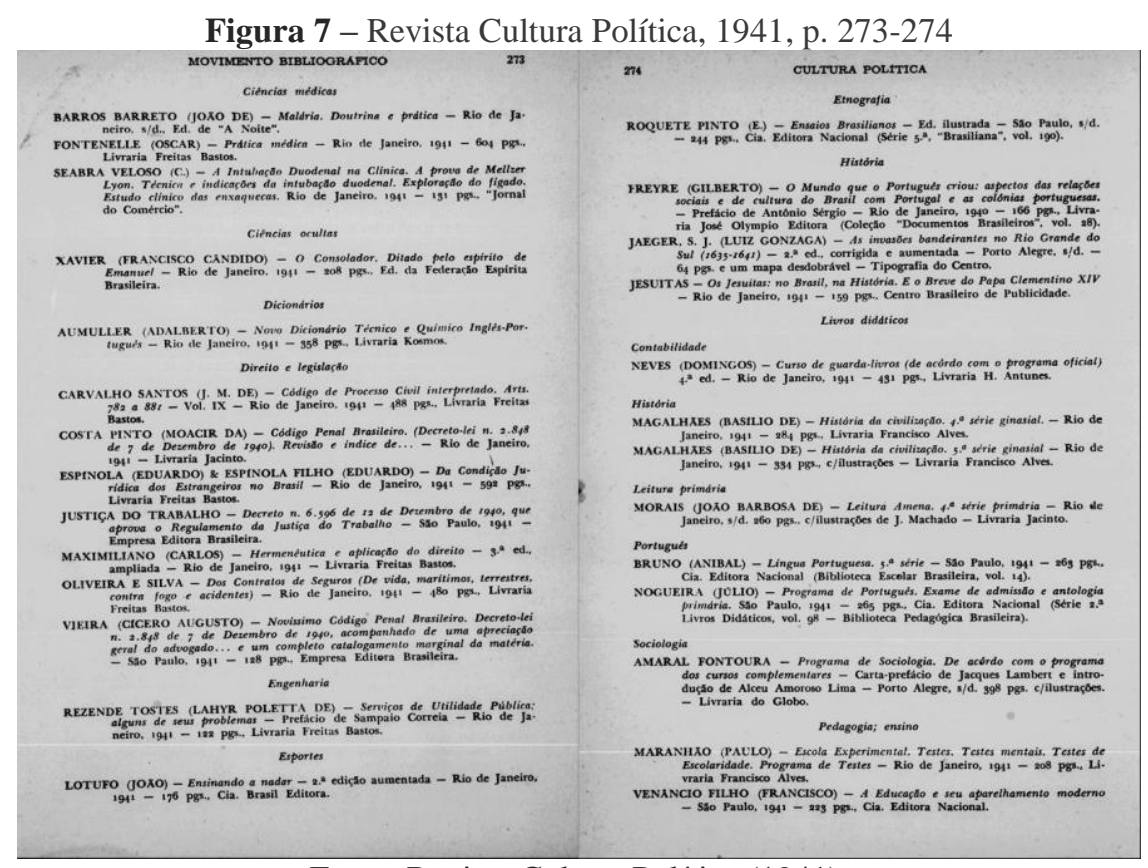

Fonte: Revista Cultura Política (1941).

Nesta seção (g), é abordado um plano chamado de publicidade especial, um procedimento estratégico para que os livros fossem alcançados e usufruídos pela nação leitora. O nome publicidade especial considera que os livros deveriam ser ilustrados, pois são as ilustrações que dão aspecto de superioridade às obras. Nesse quesito, incluíam-se a fotografia artística moderna e a pintura. As ilustrações deveriam conseguir expressar o embelezamento artístico do livro, a superioridade do valor da obra e o exterior estético (BRASIL, 1938g).

No documento chamado de 'Demonstração dos trabalhos executados pela secção de literatura infantil de 1935 a 1938 ', consta que “[...] é sabida a influência que a leitura exerce sobre nós todos e, principalmente, sobre a criança. As revistas ilustradas têm uma ação muito mais decisiva sobre o seu espírito do que as lições, os discursos e à conversação." (BRASIL, 1938a, p. 4). Em revistas, livros e cartilhas, podemos analisar a prática do referido discurso. Nas cartilhas escolares, vemos ilustrações coloridas e textos direcionados ao público específico - a juventude.

Por isso, os impressos escolares foram denominados de livros didáticos ou cartilhas escolares e aliados ao contexto político e cultural da época do estado-novista, por meio da alegoria de discursos, considerando imagem e texto 


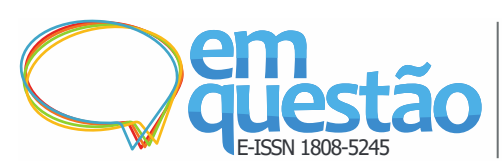

Caráter persuasivo e estrutura organizacional panóptica: as narrativas do Instituto Nacional do Livro e o Plano de Divulgação de Obras Bibliográficas no

Brasil

Alessandra Nunes de Oliveira, Jetur Lima de Castro, Luiz Eduardo Ferreira da Silva

que, muitas vezes, foram utilizados como formas de legitimar um sistema de poder como parte de políticas oficiais do Estado. Isto é, os livros, como fontes de publicidade política, passaram a ser um suporte de interlocução que veiculou valores e ideologias (COSTA; SCHMITZ; REMEDI, 2017).

A cartilha para a juventude do Estado Novo, por exemplo, traz Getúlio Vargas com crianças e jovens ensinando-as a cultuarem a pátria, o trabalho e a crítica às leituras que não correspondem ao interesse estado-novista:

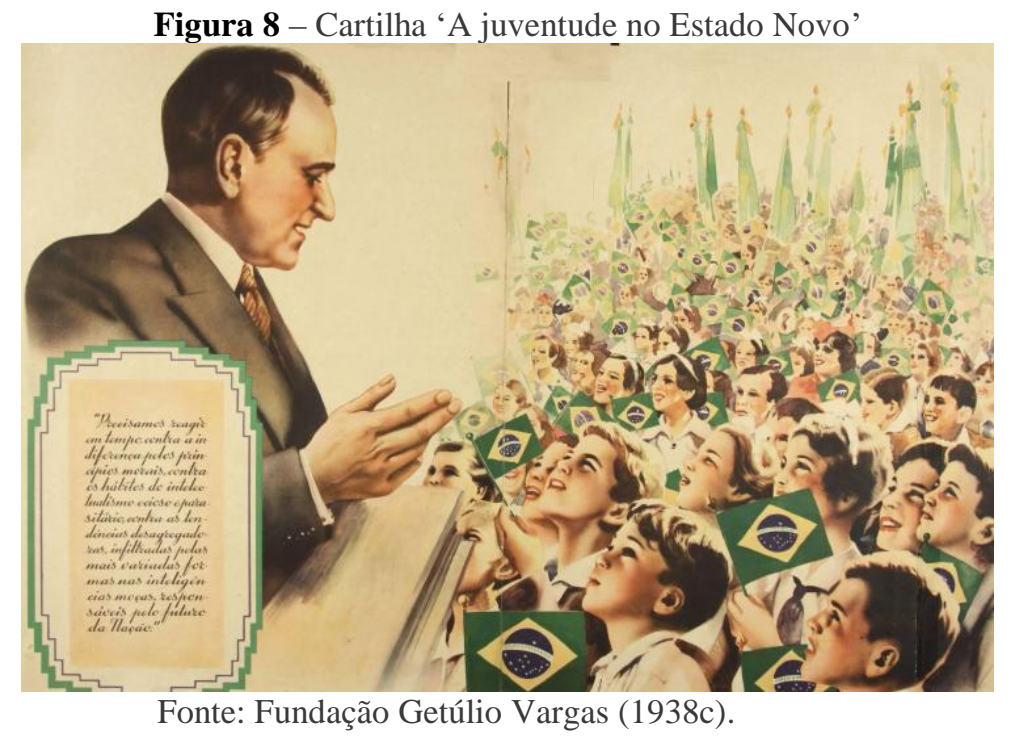

Na legenda do referente imagem acima, é prescrito que "[...] precisamos reagir em tempo contra a indiferença dos princípios morais, contra os hábitos do intelectualismo ocioso e parasitário, contra as tendências desagregadoras, infiltradas pelas mais variadas formas nas inteligências moças, responsáveis pela nação.” (FUNDAÇÃO GETÚLIO VARGAS, 1938c, p. 15).

O discurso de Vargas presente em cada página da cartilha direcionada para a juventude ou para as crianças do Estado Novo representa o que Chartier (1998) considera sobre os livros: que eles são objetos cujas formas comandam e direcionam a reprodução de sentidos do texto que carregam, de forma que os sentidos dos discursos se materializam e se tornam realidades físicas quando inscritos nas páginas de um livro, transmitidos por uma voz que lê ou narra, impulsionando como um palco de teatralização naquele que emite o discurso 


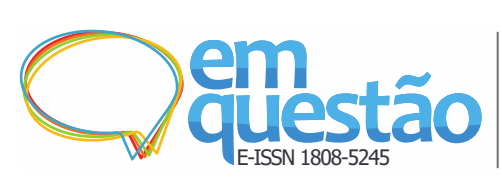

Caráter persuasivo e estrutura organizacional panóptica: as narrativas do Instituto Nacional do Livro e o Plano de Divulgação de Obras Bibliográficas no

Brasil

Alessandra Nunes de Oliveira, Jetur Lima de Castro, Luiz Eduardo Ferreira da Silva

buscando seu efeito desejado. Assim, o livro é o palco de um teatro que materializa o discurso para o público que busca direcionar.

Para que houvesse toda essa organização publicitária do INL e a divulgação das obras, foi necessário organizar a secção de controle (h), que diz respeito à organização interna e à sua projeção externa, uma vez que, conforme o acúmulo de materiais bibliográficos e de projetos com o crescimento do INL, o controle precisava ocorrer de imediato, e isso consistia em: revisar cuidadosamente os trabalhos; elaborar relatórios ligeiros, estatísticas, fichários das publicações e fichários de bibliotecas, separando-as por finalidade e classe social, "[...] impondo-se a censura dos livros de educação e de literatura, principalmente dedicados à mocidade escolar." (BRASIL, 1938g, p. 20).

\section{Considerações finais}

A pesquisa contribuiu para analisarmos o plano do INL, que contava com cerca de 88 folhas, entre gráficos e planejamentos. Inicialmente, é fácil se deixar induzir pelo discurso de propagação dos livros e das bibliotecas e pensar que é uma atitude benéfica, uma vez que foi detalhadamente organizada em favor da educação e da cultura. Entretanto, quando nos aprofundamos de maneira crítica, vemos o que ele buscava realizar com toda a sua estratégia e que ele estava direcionando para uma espécie de controle, numa estrutura persuasiva e panóptica, que derivou de práticas de censura sobre o que deveria ser lido e consumido pelos leitores das letras. Assim, extraía toda a diversidade de pensamento que não condizia com o ideal do governo estado-novista.

De outra maneira, reflete-se sobre como esses discursos disciplinares, principalmente os institucionais, como foi o PNDOB com o INL, expressam ordens hegemônicas em sua significação interior e, como bem considera Chartier (1998), uma ordem de múltiplas fisionomias que, para nós, faz com que surjam nos livros e nas bibliotecas discursos aparentes e que pressupõem práticas benéficas para a sociedade. Todavia, devem ser analisados criticamente para se saber se ali não reside um plano estratégico de interesse dos que estão disseminando as ideias, uma vez que discursos que envolvem planos de 


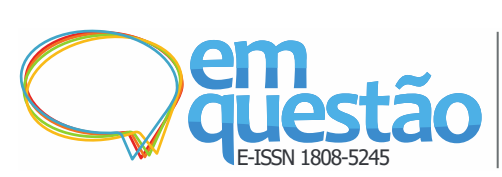

Caráter persuasivo e estrutura organizacional panóptica: as narrativas do Instituto Nacional do Livro e o Plano de Divulgação de Obras Bibliográficas no

Brasil

Alessandra Nunes de Oliveira, Jetur Lima de Castro, Luiz Eduardo Ferreira da Silva

disseminação de livros devem ser avaliados além da superfície, porque são feitos justamente para atrair o público irrefletido.

Por certo, se o plano do INL fosse feito sem os jogos de interesses políticos de homogeneizar a cultura através dos livros, seria um ótimo plano, para que as bibliotecas tivessem sua valoração pela diversidade, e os livros chegassem para grande parte da população. Porém, por trás dessa espetacularização, autores foram censurados, e a leitura foi centralizada como forma de domesticar o pensamento do povo brasileiro, e com a liberdade intelectual comprometida. Neste caso, não se pode reverenciar tal ato.

Convém lembrar que, quando falamos de ideias centralizadoras ou excludentes, estamos falando não apenas da parte física de obras e das bibliotecas, mas também de que isso se reverbera nos bibliotecários e em suas práticas, pois esses profissionais não poderão mais exercer sua especialidade da forma livre do cunho humanístico, porque a informação precisa ser disseminada, mas eles não terão que se submeter às doutrinas dos que estão acima deles. A informação será disseminada como o poder quer, e os que não estão dispostos a fazer tal ato também poderão ser excluídos. Do mesmo modo, a informação que não coincidir com o ideal de governo será descartada, uma vez que, conforme vemos no plano, todos tinham que seguir o mesmo espírito.

Devemos estar atentos a isso, porque, como pesquisadores da área da Informação e profissionais bibliotecários, devemos colocar em prática nossa visão crítica sobre os discursos que envolvem o manuseio dos livros e das bibliotecas, aparentemente benéficos e dialogais, com sincronização normativa, mas que são como 'ervas daninhas', buscando lugar para perpetuar a ideologia centralizadora, excludente e que excetua não apenas os livros e os autores, mas também os que buscam disseminar as informações, caso não obedeçam ao plano institucional.

Não podemos pensar que isso só aconteceu na década de 1930 ou 1940, mas devemos estar atentos aos próximos discursos que podem surgir em outros momentos históricos, uma vez que o livro e as bibliotecas sempre fazem parte do plano dos governos que impõem sua ideologia para "educar" conforme seus 


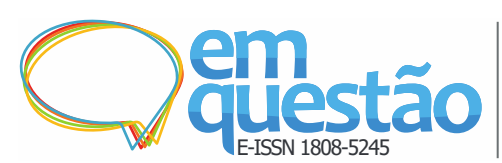

Caráter persuasivo e estrutura organizacional panóptica: as narrativas do Instituto Nacional do Livro e o Plano de Divulgação de Obras Bibliográficas no Brasil

Alessandra Nunes de Oliveira, Jetur Lima de Castro, Luiz Eduardo Ferreira da Silva

interesses. É interessante ressaltar que a liberdade intelectual gera incômodo em opressores desde os tempos mais remotos.

\section{Referências}

ARQUIVO GUSTAVO CAPANEMA, 2021 (online). Disponível em: https://docvirt.com/docreader.net/docmulti.aspx?bib=fgv_gc. Acesso em: 22 jun. 2021.

BARBOSA, Marialva Carlos. Imprensa e poder no Brasil pós-1930. Em Questão, Porto Alegre, v. 12, n. 2, jun./dez. 2006.

BARDIN, Laurence. Análise de conteúdo. Portugal: Edições70, 2009.

BENTHAM, Jeremy. O Panóptico. Belo Horizonte: Autêntica, 2000.

BORKO, Harold. Information science. What is it? American

Documentation, [S.l.], v.19, n.1, p.3-5, 1968.

BRASIL. Decreto-Lei n. 93 - de 21 de dezembro de 1937. Cria o Instituto Nacional do Livro. Rio de Janeiro, 21 dezembro de 1937, $116^{\circ}$ da independência, $49^{\circ}$ da República. Disponível em:

https://docvirt.com/docreader.net/ARQ_GC_G/5963. Acesso em: 09 jan. 2021.

BRASIL. Ministério da Educação e Saúde. Assuntos políticos. Demonstração dos trabalhos executados pela secção de literatura infantil de 1935 a 1938. Rio de Janeiro, RJ: Ministério da Educação e Saúde Pública, 24 maio 1938a. Disponível em: https://docvirt.com/docreader.net/ARQ_GC_I/2136. Acesso em: 10 jan. 2021.

BRASIL. Ministério da Educação e Saúde. Colaboração alheia. Rio de Janeiro, RJ: Ministério da Educação e Saúde Pública, 1938b. Disponível em:

https://docvirt.com/docreader.net/ARQ_GC_G/6041. Acesso em: 10 jan. 2021.

BRASIL. Ministério da Educação e Saúde. Matéria de divulgação. Rio de Janeiro, RJ: Ministério da Educação e Saúde Pública, 1938c. Disponível em: https://docvirt.com/docreader.net/ARQ_GC_G/6040. Acesso em: 10 jan. 2021.

BRASIL. Ministério da Educação e Saúde. Orientação Constitucional Brasileira dos Livros. Rio de Janeiro, RJ: Ministério da Educação e Saúde Pública, 1938d. Disponível em:

https://docvirt.com/docreader.net/ARQ_GC_G/6032. Acesso em: 09 jan. 2021.

BRASIL. Ministério da Educação e Saúde. Orientação Nacional Brasileira dos Livros. Rio de Janeiro, RJ: Ministério da Educação e Saúde Pública, 1938e. 
Disponível em: https://docvirt.com/docreader.net/ARQ_GC_G/6035. Acesso em: 09 jan. 2021.

BRASIL. Ministério da Educação e Saúde. Plano de divulgação de obras para o Instituto Nacional do Livro. Rio de Janeiro, RJ: Ministério da Educação e Saúde Pública, 1938f. Disponível em:

https://docvirt.com/docreader.net/ARQ_GC_G/6029. Acesso em: 06 jan. 2021.

BRASIL. Ministério da Educação e Saúde. Plano de divulgação de obras: $2^{\mathrm{a}}$ parte. Rio de Janeiro, RJ: Ministério da Educação e Saúde Pública, 1938g. Disponível em: https://docvirt.com/docreader.net/ARQ_GC_G/6039. Acesso em: 06 jan. 2021.

BRASIL. Ministério da Educação e Saúde. Publicidade Geral. Rio de Janeiro, RJ: Ministério da Educação e Saúde Pública, 1938h. Disponível em: https://docvirt.com/docreader.net/ARQ_GC_G/6041. Acesso em: 10 jan. 2021.

BRASIL. Ministério da educação e saúde. Realizações preliminares. Rio de Janeiro, RJ: Ministério da Educação e Saúde Pública, 1938i. Disponível em: https://docvirt.com/docreader.net/ARQ_GC_G/6039. Acesso em: 10 jan. 2021.

BRASIL. Ministério da Educação e Saúde. Serviços bibliográficos. Rio de Janeiro, RJ: Ministério da Educação e Saúde Pública, 24 maio, 1939a. Disponível em: https://docvirt.com/docreader.net/ARQ_GC_F/10657. Acesso em: 10 jan. 2021.

BRASIL. Ministério da Educação e Saúde. Anteprojeto da lei que institui o Serviço Brasileiro de Intercâmbio Intelectual. Rio de Janeiro, RJ: Ministério da Educação e Saúde Pública, 24 maio 1939b. Disponível em:

https://docvirt.com/docreader.net/ARQ_GC_F/10652. Acesso em: 10 jan. 2021.

CAPANEMA, Gustavo. Exposição de motivos. Rio de Janeiro: Ministério da Educação e Saúde, 1937. Disponível em:

https://docvirt.com/docreader.net/ARQ_GC_G/5962. Acesso em: 07 jan. 2021.

CHARTIER, Roger. A ordem dos livros: leitores, autores e bibliotecas na Europa entre os Séculos XIV e XVII. Brasília: Editora Universidade de Brasília, 1998.

CORREIO DA MANHÃ. O interesse pelo livro em todo o país: mais de 215 volumes distribuídos em todo o Brasil. Rio de Janeiro, 16 jun. 1943. Disponível em: http://memoria.bn.br/DocReader/089842_05/16398. Acesso em 10 já. 2021.

COSTA, Miguel Ângelo Silva da; SCHMITZ, Zenaide Inês; José REMEDI, Martinho Rodrigues. Cartilhas escolares e doutrinação infantil no contexto do Estado Novo (1937-1945). Revista Educação Unisinos, Porto Alegre, v. 21, n. 2, maio/ago. 2017. 
DARNTON, Robert. Censores em ação: como os estados influenciaram a literatura. Rio de Janeiro: Companhia das Letras, 2016.

FOUCAULT, Michel. Vigiar e punir: nascimento da prisão. Vozes: Petrópolis, 1987.

FUNDAÇÃO BIBLIOTECA NACIONAL. Hemeroteca digital. c2020.

Disponível em: http://bndigital.bn.gov.br/hemeroteca-digital/. Acesso em: 6 mar. 2021.

FUNDAÇÃO GETÚLIO VARGAS. Centro de Pesquisa e Documentação de História Contemporânea do Brasil. Arquivo Gustavo Capanema. Livrarias paraenses com a lista de livros editados. Rio de Janeiro: Ministério da Educação e Saúde Pública, 1938a. Disponível em:

https://docvirt.com/docreader.net/arq_gc_g/4563. Acesso em: 7 jan. 2021.

FUNDAÇÃO GETÚLIO VARGAS. Centro de Pesquisa e Documentação de História Contemporânea do Brasil. Arquivo Gustavo Capanema. Livraria Editora Chignone e Cia, Salvador - Bahia. Lista de livros editados. Rio de Janeiro, RJ: Ministério da Educação e Saúde Pública, 1938b. Disponível em: https://docvirt.com/docreader.net/arq_gc_g/4598. Acesso em: 07 jan. 2021.

FUNDAÇÃO GETÚLIO VARGAS. Centro de Pesquisa e Documentação de História Contemporânea do Brasil. Exposição virtual. Cartilha a Juventude no Estado Novo. Rio de Janeiro, RJ: Ministério da Educação e Saúde Pública, 1938c. Disponível em: https://expo-virtual-cpdoc.fgv.br/sites/expo-virtualcpdoc.fgv.br/files/documentos/gv-133f_1.pdf. Acesso em: 07 jan. 2021.

GAZETA DE NOTÍCIAS. A regulamentação do Instituto do Livro. Rio de Janeiro, 14 jan. 1938. Disponível em:

http://memoria.bn.br/DocReader/103730_06/15528. Acesso em: 08 jan. 2021. GUGLIOTTA, Alexandre Carlos; GONZÁLEZ DE GOMEZ, Maria Nélida; FONSECA, Vitor. Informação a serviço do estado burocrático: o caso do governo Vargas (1930-1945). In: XVIII ENCONTRO NACIONAL DE PESQUISA EM CIÊNCIA DA INFORMAÇÃO - ENANCIB, 2017, Marília. Anais [...]. Marília, SP: UNESP, 2017.

JOLY, Martine. Introdução à análise da imagem. Campinas-SP: Papirus, 1996.

KRIPKA, Rosana Maria Luvezute; SCHELLER, Morgana; BONOTTO, Danusa de Lara. Pesquisa documental: considerações sobre conceitos e características na pesquisa qualitativa. Atas - Investigação qualitativa na Educação, v. 2. 2015. 
LARA, Marilda Lopes Ginez de; CONTI, Vivaldo Luiz.

Disseminação da informação e usuários. São Paulo Perspec.,v.17, n.3-4, p.26-34, dez. 2003.

LEITÃO, Bárbara Júlia Menezello. A relação entre bibliotecas públicas, bibliotecários e censura na Era Vargas e Regime Militar: uma reflexão. 2010. Tese (Doutorado em Teoria e Pesquisa em Comunicação) - Escola de Comunicações e Artes, Universidade de São Paulo, São Paulo, 2010.

LOURENÇO, Frederico Ricardo de Ribeiro. Poder e norma: Michel Foucault e a aplicação do Direito. Porto Alegre: Núria Fabris Ed., 2009.

MARCONI, Marina de Andrade; LAKATOS, Eva Maria. Fundamentos de metodologia científica. 7. ed. São Paulo: Atlas, 2010.

MORIGI, Valdir José; SEHN, Ana Paula; MASSONI, Luís Fernando Herbert. Mediações da informação e da comunicação: Porto Alegre nas narrativas do Jornal Zero Hora. Ciência da Informação, Brasília, v. 43, n. 2, 2014.

OLIVEIRA, Alessandra Nunes de; CASTRO, Jetur Lima de. Entre a censura e a disseminação: uma análise crítica sobre a prática profissional bibliotecária fundada na emancipação de informação e dignidade humana. Páginas A\&B, Arquivos e Bibliotecas (Portugal), [S.l.], n. 7, p. 31-50, 2017.

REVISTA CULTURA POLÍTICA. Movimento bibliográfico. Rio de Janeiro, 1941. Disponível em: http://memoria.bn.br/DocReader/163538/287. Acesso em 11 jan. 2021.

RICOEUR, Paul. A memória, a história e o esquecimento. Campinas/SP: Editora da Unicamp, 2007.

SANTOS, Rômulo Ballestê Marques dos; PORTUGAL, Francisco Teixeira. O panóptico e a economia visual moderna: do panoptismo ao paradigma panóptico na obra de Michel Foucault. Rev. psicol. polít., São Paulo, v. 19, n. 44, p. 3449, abr. 2019.

VAN DIJK, Teun A. Discurso e Poder. São Paulo: Contexto, 2018. 


\title{
Persuasive character and panoptic organizational structure: the narratives of the National Book Institute and the Plan for the Dissemination of Bibliographic Works in Brazil
}

\begin{abstract}
It investigates the narratives presented in the National Plan for the Dissemination of Bibliographic Works (PNDOB) on the measures for the implementation of the cultural dissemination of books and libraries in the Estado Novo in Brazil. Through the documentary appropriation of Gustavo Capanema's archive and newspapers at the time, the research went the way of Critical Discourse Analysis (ACD), based on the analysis of content and images on the paths and actions adopted by the National Book Institute (INL), with the objective of analyzing how the PNDOB occurred and was structured. The use of documentary sources was necessary to discuss how the actions of the INL were widely disseminated in a persuasive and panoptic structure, through which the PNDOB was established with the objective of monitoring and controlling the books, applied to the disciplinary institution, aiming at correction and order in the name of morals and good customs. For this reason, it was questioned to what extent it is possible to consider that the publications and initiatives created by the INL were beneficial to society in the Estado Novo period, because, even though there was all the apparent dissemination of books and libraries, other types of books were considered harmful to society and sought in all corners of Brazil to get out of circulation. The results indicated the PNDOB of the INL with a persuasive and panoptic structure and a volume close to 88 sheets, among numerous graphs, organization charts and planning. It is concluded that it is possible to think about whether the actions of the INL found a beneficial attitude, since it was organized in detail in favor of education and the varguista culture of the constant expansion of information under the order of bibliographic control, and how access to knowledge and information policies happened through books in Brazil.
\end{abstract}

Keywords: Estado Novo - Brazil. Instituto Nacional do Livro. Censorship. Control of bibliographic works.

Recebido: 20/01/2021

Aceito: 07/05/2021

\section{Declaração de autoria}

Concepção e elaboração do estudo: Alessandra Nunes de Oliveira, Jetur Lima de Castro, Luiz Eduardo Ferreira da Silva.

Coleta de dados: Alessandra Nunes de Oliveira, Jetur Lima de Castro, Luiz Eduardo Ferreira da Silva. 
Alessandra Nunes de Oliveira, Jetur Lima de Castro, Luiz Eduardo Ferreira da Silva

Análise e interpretação de dados: Alessandra Nunes de Oliveira, Jetur Lima de Castro, Luiz Eduardo Ferreira da Silva.

Redação: Alessandra Nunes de Oliveira, Jetur Lima de Castro, Luiz Eduardo Ferreira da Silva.

Revisão crítica do manuscrito: Alessandra Nunes de Oliveira, Jetur Lima de Castro, Luiz Eduardo Ferreira da Silva.

\section{Como citar}

OLIVEIRA, Alessandra Nunes de; CASTRO, Jetur Lima de; SILVA, Luiz Eduardo Ferreira da. Caráter persuasivo e estrutura organizacional panóptica: as narrativas do Instituto Nacional do Livro e o Plano de Divulgação de Obras Bibliográficas no Brasil. Em Questão, Porto Alegre, v. 27, n. 4, p 296-327, 2021. Doi: http://dx.doi.org/10.19132/1808-5245274.296-327 